\title{
Inhibition of caspase-8 activity reduces IFN- $\gamma$ expression by $T$ cells from Leishmania major infection
}

\author{
WÂNIA F. PEREIRA, LANDI V.C. GUILLERMO, FLÁVIA L. RIBEIRO-GOMES \\ and MARCELA F. LOPES \\ Instituto de Biofísica Carlos Chagas Filho, Centro de Ciências da Saúde, Universidade Federal do Rio de Janeiro, \\ Av. Carlos Chagas Filho, Ilha do Fundão, 21941-902 Rio de Janeiro, RJ, Brasil \\ Manuscript received on July 11, 2007; accepted for publication on August 15, 2007; \\ presented by ROGERIO MENEGHINI
}

\begin{abstract}
Following infection with Leishmania major, $\mathrm{T}$ cell activation and apoptosis can be detected in draining lymph nodes of C57BL/6-infected mice. We investigated the mechanisms involved in apoptosis and cytokine expression following $\mathrm{T}$ cell activation. After two weeks of infection, apoptotic $\mathrm{T}$ cells were not detected in draining lymph nodes but activation with anti-CD3 induced apoptosis in both CD4 and CD8 T cells. Treatment with anti-Fas Ligand, caspase-8 or caspase9 inhibitors did not block activation-induced T-cell death. We also investigated whether the blockade of caspase- 8 activity would affect the expression of type- 1 or type- 2 cytokines. At early stages of infection, both CD4 and CD8 T cells expressed IFN- $\gamma$ upon activation. Treatment with the caspase-8 inhibitor zIETD-fmk (benzyl-oxycarbonyl-Ile$\mathrm{Glu}(\mathrm{OMe})-\mathrm{Thr}-\mathrm{Asp}(\mathrm{OMe})$-fluoromethyl ketone) reduced the proportion of CD8 T cells and IFN- $\gamma$ expression in both CD4 and CD8 T cells. We conclude that a non apoptotic role of caspase-8 activity may be required for T cell-mediated type-1 responses during L. major infection.
\end{abstract}

Key words: apoptosis, caspase-8, CD8 T cells, IFN- $\gamma$, Leishmaniasis.

\section{INTRODUCTION}

Immunity to Leishmania infection correlates with protective type 1 response in resistant hosts. CD4 Th1 cells have been considered as a major source of IFN- $\gamma$, with NK cells and CD8 $\mathrm{T}$ cells playing a minor role in primary infection (McMahon-Pratt and Alexander 2004). Susceptibility to Leishmania major infection has been associated with type 2 cytokine responses; whereas IL-10 contributes to parasite persistence (Belkaid et al. 2002a), the role of IL-4 produced by CD4 Th2 cells remains controversial (Mohrs et al. 1999, Noben-Trauth et al. 1999, Noben-Trauth et al. 2003).

Apoptosis of both CD4 and CD8 T cells has been observed within cutaneous lesions in human leishmaniasis (Bertho et al. 2000), as well as in lymph nodes from mice

Correspondence to: Marcela de Freitas Lopes

E-mail: marcelal @, biof.ufrj.br infected with L. major (Desbarats et al. 2000). Apoptosis contributes to T cell anergy to Leishmania amazonensis antigens (Pinheiro et al. 2004), but the mechanisms involved in $\mathrm{T}$ cell death in cutaneous leishmaniasis are not known.

$\mathrm{T}$ cell apoptosis can be mediated by intrinsic pathway involving growth factor deprivation and caspase-9 activation (Alves et al. 2007). By contrast, activationinduced cell death (AICD) occurs upon induction of Fas Ligand (FasL) expression, interaction with death receptor Fas and recruitment of caspase-8 (Lenardo et al. 1999, Krammer 2000). Caspase-8 is also involved in T cell signaling for proliferation, IL-2 production and development of CD8 T cell memory (Alam et al. 1999, Kennedy et al. 1999, Chun et al. 2002, Wu et al. 2004).

We investigated the role of caspase- 8 in T-cell apoptosis and control of cytokine responses in draining lymph nodes upon L. major infection. Activation-in- 
duced $\mathrm{T}$ cell death occurs in both CD4 and CD8 T cells from infected mice. Nonetheless, inhibitors of FasL, caspase- 8 or caspase- 9 did not affect $\mathrm{T}$ cell apoptosis, whereas caspase- 8 inhibition reduced IFN- $\gamma$ expression upon stimulation of $\mathrm{T}$ cells. These results suggest that caspase- 8 activity may be required in the development of protective immune responses to Leishmania infection.

\section{MATERIALS AND METHODS}

\section{MICE AND L. major INFECTION}

Female C57BL/6 mice were obtained from the Federal University of Rio de Janeiro. L. major LV39 isolated from BALB/c mice were cultured in Schneider's medium at $28^{\circ} \mathrm{C}$ during 4 days and used at the stationary phase of the culture. Mice, aging 7-9 wk, were infected in the left hind footpad with sc injection of $3 \times 10^{6}$ metacyclic promastigotes $/ 30 \mu \mathrm{L}$. Mice were killed during the acute phase at 2, 6, and 13 weeks post infection. All experiments and animal handling were conducted according to approved institutional protocols.

\section{Cell Suspensions And Cultures}

Cells were obtained from draining (popliteal) lymph nodes from infected mice or from a pool of inguinal and popliteal lymph nodes from normal mice. Cells were re-suspended in DMEM (Invitrogen Life Technologies), supplemented with $2 \mathrm{mM}$ glutamine, $5 \times 10^{-5} \mathrm{M}$ 2-ME, $10 \mu \mathrm{g} / \mathrm{mL}$ gentamicin, $1 \mathrm{mM}$ sodium pyruvate, $0.1 \mathrm{mM}$ MEM nonessential amino acids, and $10 \mathrm{mM}$ HEPES plus 10\% FBS (Invitrogen Life Technologies). Cells $\left(1 \times 10^{6} / 0.5 \mathrm{~mL}\right)$ were cultured in duplicate in medium only or stimulated with $10 \mu \mathrm{g} / \mathrm{mL}$ plate-bound anti-CD3 (mAb 2C11; BD Pharmingen) in 48-well vessels. Cultures were set at $37^{\circ} \mathrm{C}$ and $7 \% \mathrm{CO}_{2}$ in a humid atmosphere for $24 \mathrm{~h}$. In some experiments, cells were activated with anti-CD3 and incubated with $10 \mu \mathrm{g} /$ $\mathrm{mL}$ anti-FasL (clone MFL3) or IgG control mAb (BD Pharmingen), or with $40 \mu \mathrm{M}$ of caspase- 8 inhibitor zIETD (zIETD-fmk: benzyl-oxycarbonyl-Ile-Glu(OMe)Thr-Asp(OMe)-fluoromethyl ketone), or caspase-9 inhibitor zLEHD (zLEHD-fmk: benzyl-oxycarbonyl-LeuGlu(OMe)-His-Asp(OMe)-fmk) from Enzyme System Products, or $0.4 \%$ DMSO as stock diluent control. Apoptosis was evaluated in $\mathrm{T}$ cell subsets by flow cytometry as described below.

\section{FLOW CYTOMETRY}

Fresh or cultured cells were washed in sorting buffer (containing 2\% FBS) and incubated with anti-CD16/ CD32 for Fc blocking, followed by staining with allophycocyanin-labeled anti-CD8 or anti-CD4 for $30 \mathrm{~min}$ at $4^{\circ} \mathrm{C}$. All mAbs used in flow cytometry are from BD Pharmingen. For apoptosis detection, cells were washed to remove excess of surface staining reagents, and then stained with FITC-annexin V (apoptosis detection kit; R\&D Systems) for $20 \mathrm{~min}$ at room temperature in annexin buffer or with 7-AAD, which was added just prior to flow cytometry. Cells were also stained with FITClabeled anti-CD44 as a marker for T cell activation. Cells were washed and acquired on a FACSCalibur system, by using Cell quest software (BD Biosciences). For analysis, FlowJo software was used (TreeStar).

\section{INTRACELLULAR CYTOKINES}

Lymph node cells $\left(1 \times 10^{6} / 0.5 \mathrm{~mL}\right)$ obtained from $L$. major-infected mice ( $2 \mathrm{wk}$ upon infection) were cultured in 48 well plates with plate bound anti-CD3 $(10 \mu \mathrm{g} / \mathrm{mL})$ in the presence or absence of IL-4 $(1 \mathrm{ng} / \mathrm{mL})$, zIETD $(40 \mu \mathrm{M})$ or $0.4 \%$ DMSO. Upon $72 \mathrm{~h}$, PMA (10 ng/mL) and ionomycin $(0.5 \mu \mathrm{g} / \mathrm{mL})$ from Sigma were added to cultures. Some cultures were left without further stimulation. After $1 \mathrm{~h}$, brefeldin A (10 $\mu \mathrm{g} / \mathrm{mL}$, Sigma) was added to all cells. Cells were collected upon $3 \mathrm{~h}$, counted, stained, and analyzed by flow cytometry. For surface markers, cells were treated with allophycocyanin-labeled anti-CD8 or anti-CD4, washed, fixed and stained with PE-anti-IL-10 and FITC-anti-IFN $\gamma$.

\section{DATA ANALYSis}

Results are expressed as average and SEM in figures and the number $(n)$ of animals per group was indicated in figure legend. For in vitro experiments, data are expressed as average of 2-3 determinations per treatment, in each of at least 3 repeat experiments, and significant differences detected in Student's t test were shown for $p<0.05\left(^{*}\right)$.

\section{RESULTS}

\section{T CELL APOptosis DuRING L.major INFECTION}

We infected B6 mice in the footpads with L. major and followed the onset of activation and apoptosis in T cells from draining (popliteal) lymph nodes. Increased ex- 
A

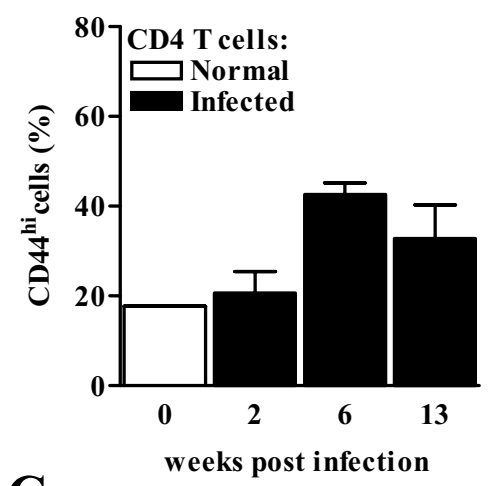

C

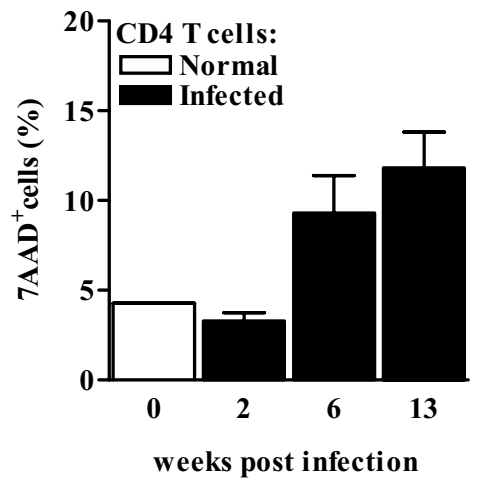

B
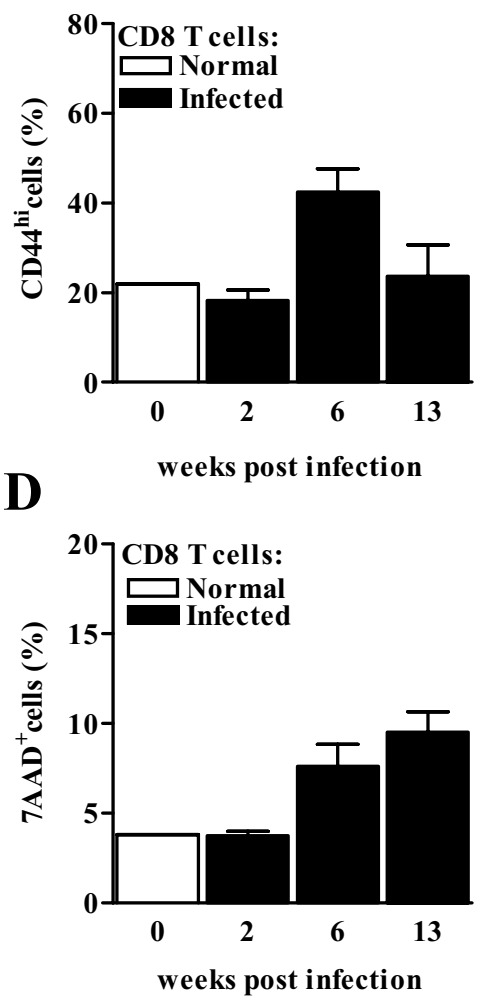

Fig. $1-\mathrm{T}$ cell activation and apoptosis during L. major infection. Lymph node cells from normal and L. major-infected mice were analysed by flow cytometry. Activation of CD4 (A) and CD8 (B) T cells was determined by high expression of CD44. Apoptosis was assed upon staining with 7-AAD in CD4 (C) and CD8 (D) T cells. Open bars represents T-cell activation and apoptosis in a pool of (inguinal and popliteal) lymph nodes from normal mice, black bars represent draining (popliteal) lymph nodes from $L$. major-infected mice. Results are expressed as average and SEM ( $\mathrm{n}=2-3$ mice/group).

pression of CD44 and staining with 7-AAD were assessed as markers of activation and apoptosis in T cells, respectively. We observed increased activation and apoptosis $6 \mathrm{wk}$ upon L. major infection in both CD4 and CD8 T cells (Fig. 1). After 13 wk of infection, however, activation returned to baseline levels (Fig. 1A and B), whereas apoptosis remained elevated (Fig. 1C and D). We investigated the mechanisms of $\mathrm{T}$ cell apoptosis in vitro. Activation with anti-CD3 induced apoptosis in both CD4 and CD8 T cells from draining lymph nodes as early as 2 wk (Fig. 2A and B) upon infection with $L$. major. AICD was more evident in CD4 than in CD8 T cells upon 2 (Fig. 2A and B) or 6 (Fig. 2C and D) wk of infection. To investigate the role of Fas-death path- way, we treated $\mathrm{T}$ cell cultures with anti-FasL or control $\mathrm{IgG}$ antibody and assessed apoptosis by annexin V staining upon $24 \mathrm{~h}$. Treatment with anti-FasL did not inhibit apoptosis induced upon $\mathrm{T}$ cell activation (Fig. 3A and B). To address whether caspase- 8 or caspase- 9 were involved in apoptosis, T cells were activated in the presence of caspase- 8 (zIETD) or caspase-9 (zLEHD) inhibitor. Neither zIETD nor zLEHD inhibited AICD in T cells from L. major infection (Fig. 3C and D).

\section{CASPASE-8 AND CYTOKINE EXPRESSION BY T CELLS}

Previous experiments suggest a non apoptotic role of caspases in $\mathrm{T}$ cell signaling for cytokine responses (Sehra et al. 2005, Su et al. 2005). We addressed by flow cyto- 
A

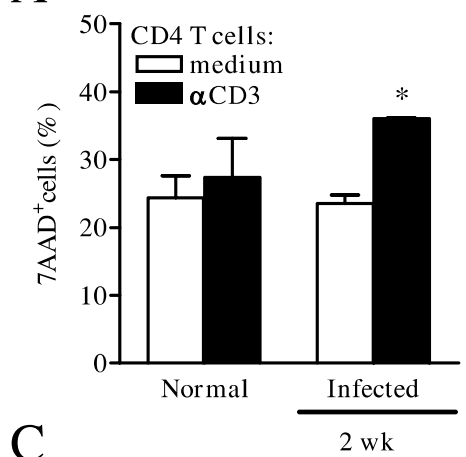

$\mathrm{C}$

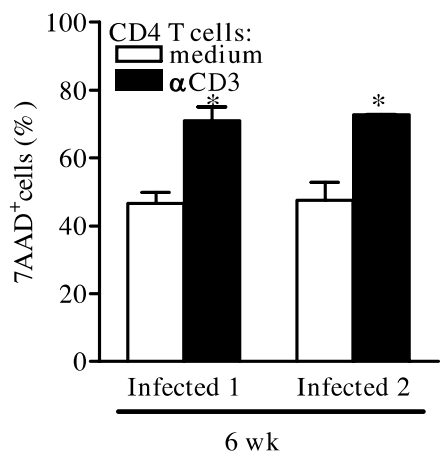

B
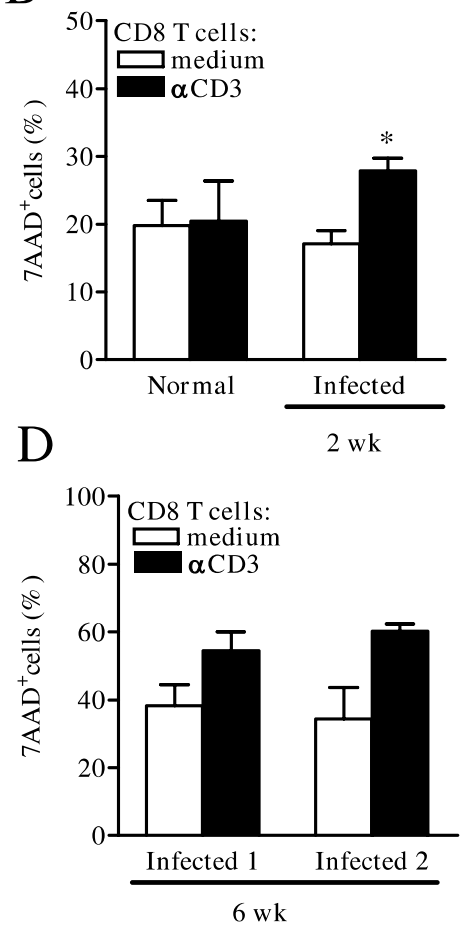

Fig. 2 - Activation-induced cell death upon infection with L. major. Lymph node cells from normal and L. major-infected mice were cultured in the presence of medium only (open bars) or stimulated with anti-CD3 (black bars). After $24 \mathrm{~h}$, cells were stained with anti-CD4 (A and C), anti-CD8 (B and D), 7-AAD and evaluated by flow cytometry. Panels show percentages of apoptotic $\left(7-\mathrm{AAD}^{+}\right) \mathrm{CD} 4$ and $\mathrm{CD} 8 \mathrm{~T}$ cells upon $2(\mathrm{~A}$ and $\mathrm{B})$ or 6 ( $\mathrm{C}$ and D) weeks of infection. Results are expressed as average and SEM. Significant differences between cells treated with medium and anti-CD3 were indicated for $p<0.05\left(^{*}\right)$.

metry cytokine expression in T cell subsets, and whether caspase- 8 controls type- $1 /$ type- 2 cytokines upon $L$. $m a$ jor infection. First, T cells from draining lymph nodes ( 2 wk post infection) were activated with anti-CD3 in the presence of caspase- 8 inhibitor zIETD or DMSO only during $72 \mathrm{~h}$. Then, T cells were re-stimulated with ionomycin and PMA, in the presence of brefeldin A, to prevent cytokine secretion. The presence of zIETD did not affect the number of cells recovered from $T$ cell cultures (not shown). The proportions of CD4 and CD8 T cells were similar (30-40\%) in cultures (Fig. 4A and B). Caspase- 8 inhibition negatively affected CD8, but not CD4, T cells (Fig. 4A and B) and the proportion of cells expressing IFN- $\gamma$, but not IL-10 (Fig. 4C and D). Both CD4 and CD8 T cells expressed IFN- $\gamma$ (Fig. 5A and B), whereas expression of IL-4 was not detected even upon culture with exogenous IL-4 (not shown). The inhibition of caspase- 8 decreased the expression of IFN- $\gamma$ in both CD4 and CD8 T cells (Fig. 5A and B). These results suggest that caspase-8 plays a role in the control of cytokine responses to L. major infection.

\section{DISCUSSION}

Apoptosis of CD4 T cells has been suggested as a mechanism to reduce Th1 responses in Leishmania donovani infection (Das et al. 1999). In addition, Fas and/or FasL expression has been detected in T cells from lymph nodes (Desbarats et al. 2000) or lesions (Eidsmo et al. 2005) during L. major infection, and mice with defective Fas/ FasL expression show increased Th1 responses upon $L$. donovani (Alexander et al. 2001) and L. major (Huang 
A

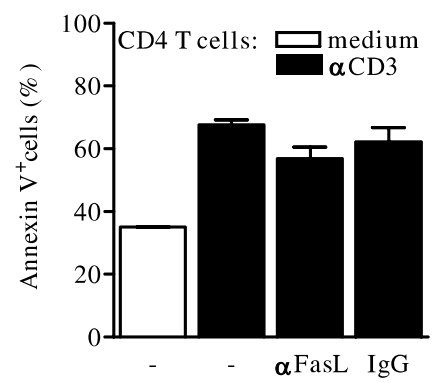

C

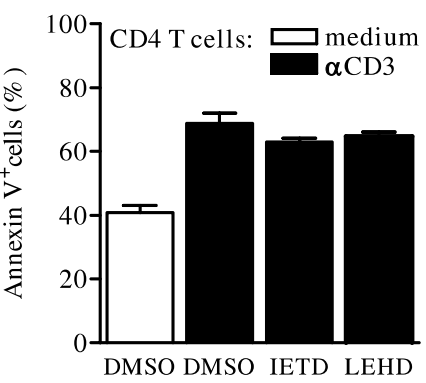

B

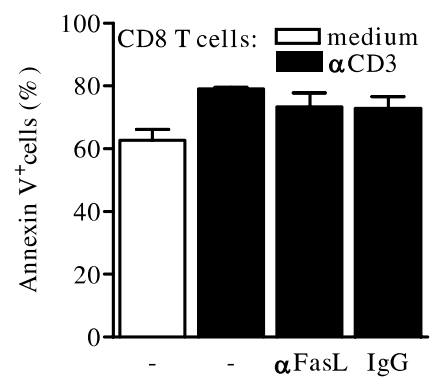

$\mathrm{D}$

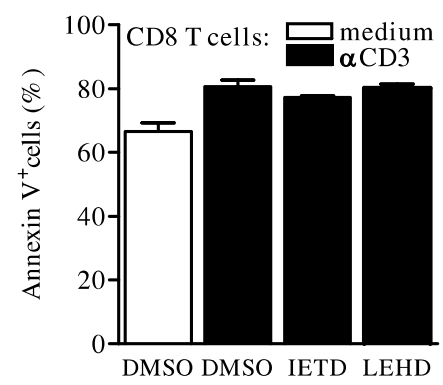

Fig. 3 - T-cell death pathways during L. major infection. Lymph node cells from infected (2 wk) mice were cultured with medium only (open bars) or stimulated with anti-CD3 (black bars) in the presence of anti-FasL or control $\operatorname{IgG}$ (A and B) or in the presence of zIETD, zLEHD or stock diluent DMSO (C and D). After $24 \mathrm{~h}$, cultured cells were stained with anti-CD4, anti-CD8, and annexin V. Panels show percentages of apoptotic (annexin $\mathrm{V}^{+}$) CD4 (A and C) and CD8 (B and D) T cells. Results are expressed as average and SEM.

et al. 1998) infections. We observed increased apoptosis in both CD4 and CD8 T cells from draining lymph nodes only at later stages of $L$. major infection. T cell apoptosis can also be induced by stimulation in vitro (AICD) as early as $2 \mathrm{wk}$ and after $6 \mathrm{wk}$, at the peak of lymphocyte activation in vivo. Nonetheless, AICD was not blocked by inhibitors of FasL, caspase- 8 or caspase9 , although these reagents have been successfully used at the same doses in previous unrelated experiments (Silva et al. 2005, Guillermo et al. 2007). Therefore, AICD in lymph nodes from L. major infection may be mediated by other mechanisms, such as granzyme-B-induced apoptosis (Devadas et al. 2006).

By contrast, caspase- 8 inhibition by zIETD peptide negatively affected CD8 $\mathrm{T}$ cells and the expression of IFN- $\gamma$ in T cells from L. major-infected mice. Similarly, CD8 $\mathrm{T}$ cells have defective survival and IFN- $\gamma$ expression in mice bearing a $\mathrm{T}$ cell-restricted transgene for the viral-FLICE/caspase- 8 inhibitory protein (vFLIP) $(\mathrm{Wu}$ et al. 2004). These results suggest a paradoxical role of caspase- 8 preventing, rather than inducing T cell death. Although caspase- 8 inhibition could affect CD8 T-cell responses during L. major infection, the role of CD8 T cells as an important source of IFN- $\gamma$ in the immunity to primary L. major infection is disputed (Huber et al. 1998, Belkaid et al. 2002b). However, it has been suggested that CD8 T cells can favor IFN- $\gamma$ expression by protective CD4 Th1 cells during L. major infection. (Herath et al. 2003).

Based on evidence suggesting a non apoptotic role of caspase- 8 in $\mathrm{T}$ cell signaling for cytokine expression (Su et al. 2005), we studied how caspase- 8 inhibition would affect the development of type-1 vs type- 2 responses following L. major infection. Caspase- 8 inhibition decreased the expression of IFN- $\gamma$ by both CD 4 and CD8 T cells. It is possible that these effects are due to defective signaling for cytokine expression upon caspase-8 inhibition as previously observed for NF- $\kappa$ B activation 
A

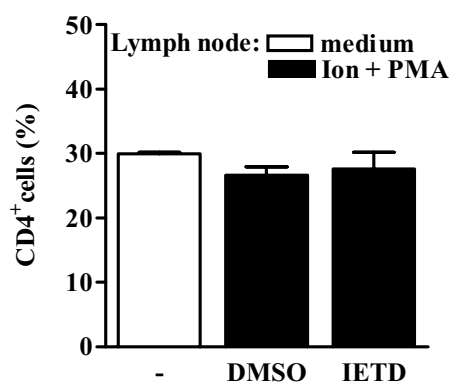

C

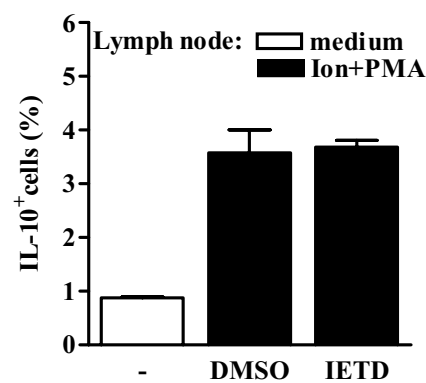

B

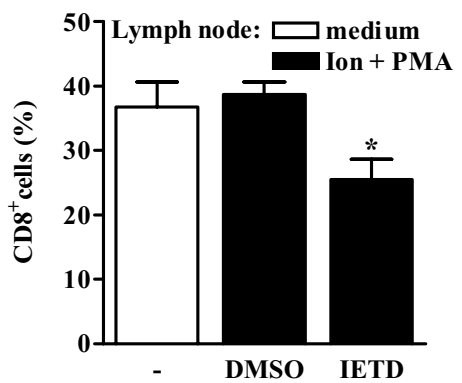

D

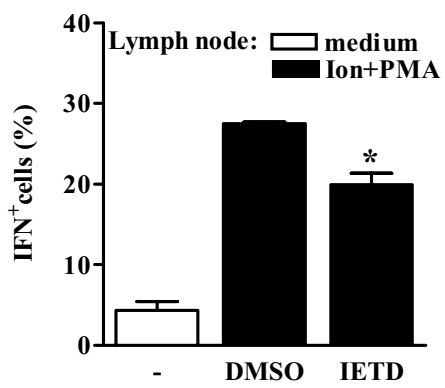

Fig. 4 - Expression of type 1 and type 2 cytokines in L. major infection. Lymph node cells from infected ( $2 \mathrm{wk}$ ) mice were stimulated with anti-CD3 only or in the presence of zIETD or stock diluent DMSO for $72 \mathrm{~h}$. Cells were re-stimulated with PMA and ionomycin for $4 \mathrm{~h}$, in the presence of brefeldin A. Cells were stained with anti-CD4 (A), anti-CD8 (B) or permeabilized and stained with anti-IL-10 (C) and anti-IFN- $\gamma$ (D). Results are expressed as average and SEM. Significant differences between cells treated with zIETD and DMSO were indicated for $p<0.05\left(^{*}\right)$.

and IL-2 secretion (Silva et al. 2005, Su et al. 2005). In agreement with this idea, defective NF- $\kappa \mathrm{B}$ activation affects negatively both proliferation and the production of IFN $-\gamma$ by T cells (Corn et al. 2003). By contrast, IL10 expression in $\mathrm{T}$ cells from $L$. major infection was not affected by inhibition of caspase- 8 even in the presence of IL-4 (not shown). Therefore, non apoptotic activity of caspase- 8 is not necessary for the expression of type2 cytokines, but may be required for the induction of protective type-1 response in L. major infection.

\section{ACKNOWLEDGMENTS}

We thank George A. DosReis (IBCCF-UFRJ) for helpful suggestions. This investigation received financial support from the UNICEF/UNDP/World Bank/WHO Special Program for Research and Training in Tropical Diseases (TDR) (grant A60281), Conselho Nacional de Desenvolvimento Científico e Tecnológico (CNPq), Fun- dação Carlos Chagas Filho de Amparo à Pesquisa do Estado do Rio de Janeiro (FAPERJ), and Institute for Investigation in Immunology (iii), Millennium Institutes, Brazilian Ministry of Science and Technology. W.F.P. receives an MSc fellowship from Coordenação de Aperfeiçoamento de Pessoal de Nível Superior (CAPES). M.F.L. is a research fellow at CNPq, Brazil.

\section{RESUMO}

A ativação e a morte por apoptose de linfócitos T foram observadas em linfonodos drenantes de camundongos C57BL/6 infectados com Leishmania major. Investigamos os mecanismos envolvidos na apoptose e na expressão de citocinas após a ativação de linfócitos T. Após duas semanas de infecção, embora as células apoptóticas ainda não sejam detectadas em linfonodos drenantes, células T CD4 e CD8 sofrem apoptose após ativação com anti-CD3. O tratamento com anticorpo antagonista anti-Ligante de Fas, ou com inibidores das caspases- 8 e 9, não 

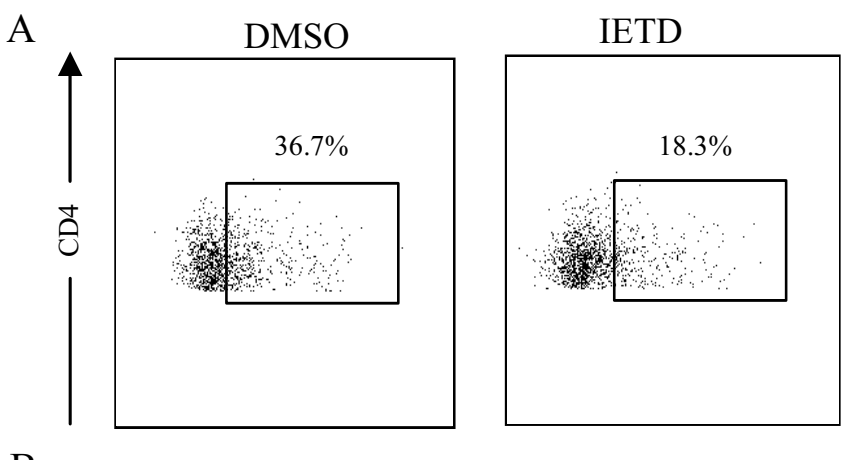

B

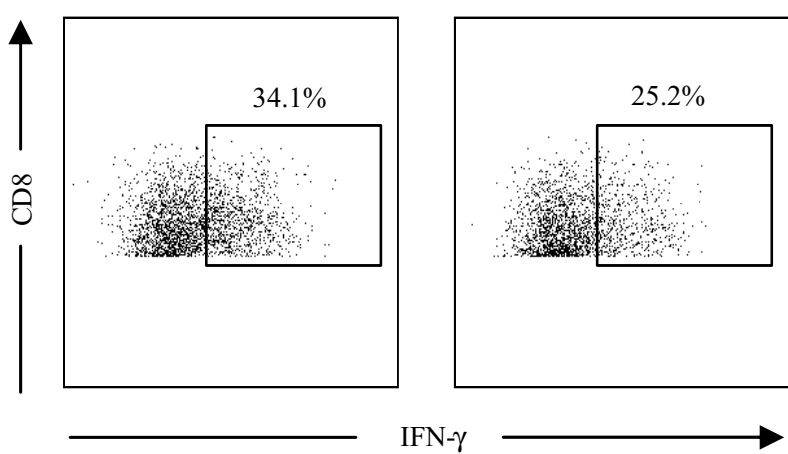

Fig. 5 - Inhibition of caspase- 8 reduces IFN- $\gamma$ expression by T cells from L. major infected mice. Lymph node cells from infected ( $2 \mathrm{wk}$ ) mice were stimulated with anti-CD3 in the presence of zIETD (right panels) or stock diluent DMSO (left panels), re-stimulated as described above and stained with anti-CD4 (A), anti-CD8 (B) and anti-IFN- $\gamma$ (A and B). Panels show percentages of IFN- $\gamma^{+} \mathrm{CD} 4 \mathrm{~T}$ cells (A), and IFN- $\gamma^{+} \mathrm{CD} 8 \mathrm{~T}$ cells (B) as assessed by flow cytometry.

bloqueou a morte induzida por ativação das células T. Investigamos também se a inibição da atividade da caspase- 8 poderia afetar a expressão de citocinas tipo-1 ou tipo-2. Nos estágios iniciais da infecção, células T CD4 e CD8 de animais infectados com L. major expressaram IFN- $\gamma$ após ativação. $\mathrm{O}$ tratamento com o inibidor de caspase-8 zIETD (benzoil-oxicarbonil-IleGlu(OMe)-Thr-Asp(OMe)-fluorometilcetona) durante a estimulação de células T reduziu a proporção de células T CD8 e a expressão de IFN- $\gamma$ por células T CD4 e CD8. Concluimos que a atividade não apoptótica de caspase- 8 pode ser necessária para o estabelecimento da imunidade mediada por células T durante a infecção por L. major.

Palavras-chave: apoptose, caspase-8, células T CD8, IFNgama, Leishmanioses.

\section{REFERENCES}

Alam A, Cohen Ly, Aouad S And Sekaly RP. 1999. Early activation of caspases during $\mathrm{T}$ lymphocyte stimula- tion results in selective substrate cleavage in nonapoptotic cells. J Exp Med 190: 1879-1890.

Alexander CE, Kaye PM and Engwerda CR. 2001. CD95 is required for the early control of parasite burden in the liver of Leishmania donovani-infected mice. Eur J Immunol 31: 1199-1210.

Alves NL, VAN Lier RA AND Eldering E. 2007. Withdrawal symptoms on display: Bcl-2 members under investigation. Trends Immunol 28: 26-32.

Belkaid Y, Piccirillo CA, Mendez S, Shevach EM AND SACKS DL. 2002a. CD4+CD25+ regulatory T cells control Leishmania major persistence and immunity. Nature 420: 502-507.

Belkaid Y, von Stebut E, Mendez S, Lira R, Caler E, Bertholet S, Udey MC and Sacks D. 2002b. CD8+ T cells are required for primary immunity in C57BL/6 mice following low-dose, intradermal challenge with Leishmania major. J Immunol 168: 3992-4000.

Bertho AL, Santiago MA, Da-Cruz AM and CouTINHO SG. 2000. Detection of early apoptosis and cell 
death in T CD4+ and CD8+ cells from lesions of patients with localized cutaneous leishmaniasis. Braz J Med Biol Res 33: 317-325.

Chun HJ ET AL. 2002. Pleiotropic defects in lymphocyte activation caused by caspase- 8 mutations lead to human immunodeficiency. Nature 419: 395-399.

CORN RA ET AL. 2003. T cell-intrinsic requirement for $\mathrm{NF}-\kappa \mathrm{B}$ induction in postdifferentiation IFN $-\gamma$ production and clonal expansion in a Th1 response. $\mathrm{J}$ Immunol 171: 1816-1824.

Das G, Vohra H, Rao K, Saha B and Mishra GC. 1999. Leishmania donovani infection of a susceptible host results in CD4+ T-cell apoptosis and decreased Th1 cytokine production. Scand J Immunol 49: 307-310.

Desbarats J, Stone Je, Lin L, Zakeri ZF, Davis GS, Pfeiffer LM, Titus RG AND Newell MK. 2000. Rapid early onset lymphocyte cell death in mice resistant, but not susceptible to Leishmania major infection. Apoptosis 5: 189-196.

Devadas S, Das J, LiU C, Zhang L, Roberts AI, PAN Z, Moore PA, Das G AND SHI Y. 2006. Granzyme B is critical for $\mathrm{T}$ cell receptor-induced cell death of type 2 helper T cells. Immunity 25: 237-247.

Eidsmo L, Nylen S, Khamesipour A, Hedblad MA, Chiodi F AND AKuffo H. 2005. The contribution of the Fas/FasL apoptotic pathway in ulcer formation during Leishmania major-induced cutaneous Leishmaniasis. Am J Pathol 166: 1099-1108.

Guillermo LV, Silva EM, Ribeiro-Gomes FL, De Meis J, Pereira WF, Yagita H, DosReis GA and LOPES MF. 2007. The Fas death pathway controls coordinated expansions of type $1 \mathrm{CD} 8$ and type 2 CD4 T cells in Trypanosoma cruzi infection. J Leukoc Biol 81: 942-951.

Herath S, Kropf P and Muller I. 2003. Cross-talk between CD8(+) and CD4(+) T cells in experimental cutaneous leishmaniasis: $\mathrm{CD} 8(+) \mathrm{T}$ cells are required for optimal IFN $-\gamma$ production by CD4(+) T cells. Parasite Immunol 25: 559-567.

Huang FP, Xu D, Esfandiari EO, Sands W, Wei XQ AND LIEW FY. 1998. Mice defective in Fas are highly susceptible to Leishmania major infection despite elevated IL-12 synthesis, strong Th1 responses, and enhanced nitric oxide production. J Immunol 160: 4143-4147.

Huber M, Timms E, MaK TW, Rollinghoff M And LOHOFF M. 1998. Effective and long-lasting immunity against the parasite Leishmania major in CD8-deficient mice. Infect Immun 66: 3968-3970.
KenNedy NJ, Kataoka T, Tschopp J AND Budd RC. 1999. Caspase activation is required for $\mathrm{T}$ cell proliferation. J Exp Med 190: 1891-1896.

KRAMMER PH. 2000. CD95's deadly mission in the immune system. Nature 407: 789-795.

Lenardo M, Chan KM, Hornung F, McFarland H, Siegel R, WAng J And Zheng L. 1999. Mature T lymphocyte apoptosis-immune regulation in a dynamic and unpredictable antigenic environment. Annu Rev Immunol 17: 221-253.

McMahon-Pratt D And Alexander J. 2004. Does the Leishmania major paradigm of pathogenesis and protection hold for New World cutaneous leishmaniases or the visceral disease? Immunol Rev 201: 206-224.

Mohrs M, Ledermann B, Kohler G, Dorfmuller A, Gessner A AND Brombacher F. 1999. Differences between IL-4- and IL-4 receptor alpha-deficient mice in chronic leishmaniasis reveal a protective role for IL-13 receptor signaling. J Immunol 162: 7302-7308.

Noben-Trauth N, Paul WE and Sacks DL. 1999. IL4- and IL-4 receptor-deficient BALB/c mice reveal differences in susceptibility to Leishmania major parasite substrains. J Immunol 162: 6132-6140.

Noben-Trauth N, Lira R, Nagase H, Paul WE and SACKS DL. 2003. The relative contribution of IL-4 receptor signaling and IL-10 to susceptibility to Leishmania major. J Immunol 170: 5152-5158.

Pinheiro RO, Pinto EF, Benedito AB, Lopes UG AND Rossi-Bergmann B. 2004. The T-cell anergy induced by Leishmania amazonensis antigens is related with defective antigen presentation and apoptosis. An Acad Bras Cienc 76: 519-527.

Sehra S, Patel D, Kusam S, Wang ZY, Chang CH AND DENT AL. 2005. A role for caspases in controlling IL-4 expression in T cells. J Immunol 174: 3440-3446.

Silva EM ET AL. 2005. Caspase-8 activity prevents type 2 cytokine responses and is required for protective $\mathrm{T}$ cellmediated immunity against Trypanosoma cruzi infection. J Immunol 174: 6314-6321.

Su H, Bidere N, Zheng L, Cubre A, Sakai K, Dale J, Salmena L, Hakem R, Straus S and Lenardo $\mathrm{M}$. 2005. Requirement for caspase- 8 in NF- $\kappa$ B activation by antigen receptor. Science 307: 1465-1468.

WU Z ET AL. 2004. Viral FLIP impairs survival of activated T cells and generation of CD8+ T cell memory. J Immunol 172: 6313-6323. 